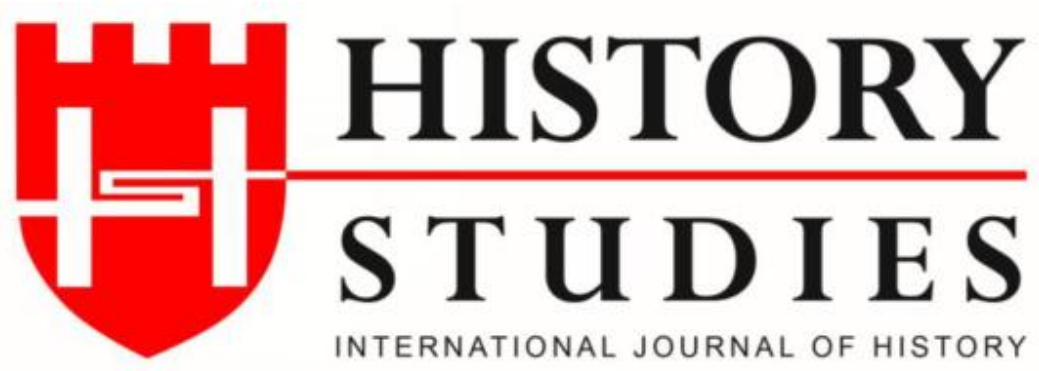

ISSN: 13094173 (Online) 1309 - 4688 (Print)

Volume 10 Issue 10, A Tribute to Prof. Dr. Yilmaz KURT, p. 267-282, December 2018

DOI Number: 10.9737/hist.2018.702

\title{
II. Abdülhamid Döneminde Ulahların İstihdamına Dair
}

On the Employment of the Vlachs in the Reign of Abdülhamid The Second

\author{
Doç. Dr. Mucize ÜNLÜ - Ahmet YADİ \\ (ORCID: 0000-0002-8263-5602 / 0000-0002-0405-3535) \\ Ondokuz Mayls Üniversitesi - Samsun
}

\begin{abstract}
Öz: Bugün Balkanlar ve Doğu Avrupa'nın çeşitli bölgelerinde yaşayan ve Latince ile irtibatl bir dil konuşan Ulahlar, Balkanların en eski sakinlerindendir. Osmanlıların Balkanlarda karşılaştığı ilk topluluklardan olan Ulahlar, XIX. yüzyıl sonlarında büyük oranda Makedonya coğrafyasında yaşamaktaydılar. Berlin Kongresi'nden sonra ortaya çıkan Makedonya Sorununun bir parçası olmuşlar ve bu süreçte Romanya tarafindan desteklenmişlerdir. Bu çalışmada 1905 yılında Osmanlı Devleti tarafindan ayrı bir millet olarak tanınan Ulahların II. Abdülhamid döneminde istihdamlarına yönelik girişimler ve istihdam edilen Ulahlar hakkında bilgi verilecektir.
\end{abstract}

Anahtar Kelimeler: Ulahlar, II. Abdülhamid Dönemi, İstihdam, Makedonya.

Abstract: Today, the Vlachs, living in various parts of the Balkans and Eastern Europe and speaking a language related to Latin, are among the oldest inhabitants of the Balkans. The Vlachs were one of the societies encountered by the Ottomans in Balkans and they lived mostly in the geography of Macedonia in the $19^{\text {th }}$ century. The Vlachs were a part of Macedonian Question which was emerged after the Berlin Congress, and the Vlachs were supported by Romania in that period. In this study, some information will be given about the employed Vlachs and the attemps to employment of the them, recognized as a seperate nation in 1905, during the reign of Abdülhamid the Second.

Keywords: The Vlachs, The Reign of Abdülhamid the Second, Employment, Macedonia.

\section{Giriş}

Günümüzde Balkanlarda ve Doğu Avrupa'nın bazı bölgelerinde yaşayan Ulahlar, Balkanların en eski sakinlerindendir. Araştırmacılar tarafından 22 farklı adı olduğu tespit edilen Ulahlar, kendileri için Aroman (Aromâni) ismini kullanırlar. ${ }^{1}$ Latin dillerinden Romence ile akraba bir dil olan Ulahça/Vlahça konuşmaktadırlar. ${ }^{2}$ Makedonlar, Teselyalılar, Antik Trakyalı, İlirler ve Epirlilerin Latinleştirilmesi sonucu ortaya çıkmış bir halk olarak kabul edilirler. ${ }^{3}$ Kökenlerinin Rumenlerle aynı olduğu, Balkanlardaki Romalıların ve

\footnotetext{
${ }^{1}$ İhsan Burak Birecikli, "Balkanlarda Unutulmuş Bir Halk: Ulahların Kısa Tarihi”, Türk Tarihinde Balkanlar, C. II, Sakarya Üniversitesi Balkan Araştırmaları Uygulama ve Araştırma Merkezi Yayınları, Sakarya 2013, s. 940.

${ }^{2}$ Tuncay Ercan Sepetçioğlu, "Türkiye'de Ana Dili Türkçe Olmayan Göçmen Topluluklara Yaklaşımlara Dair Bir Örnek: Girit Göçmenleri”, ÇTTAD, IX/20-21 (2010 Bahar-Güz), s. 84.

${ }^{3}$ Mehmet Köseoğlu, Başbakanlık Osmanlı Arş̧iv Belgelerine Göre Ulahların Siyasi, Dini ve Eğitim Faaliyetleri (1876-1910), Yüksek Lisans Tezi, Batman Üniversitesi\&Fırat Üniversitesi (Ortak Program) Sosyal Bilimler Enstitüsü, Elazı̆̆ 2015, s. 37.
} 
Romalılaştırılmış kolonilerin soyundan geldikleri söylenmektedir. ${ }^{4}$ Rumen tarihçiler de Ulahların kökenini Romalılaşmış Daçya kabilelerine veya Roma lejyonlarına dayandırır. ${ }^{5}$

Göçebe hayvan yetiştiricisi olan Ulahlar, Ortaçağda Sırbistan ile Ragusa arasındaki ticarette beygirlerle taşımacılık yaparak önemli bir rol oynamışlardır. Kendilerinden ordularda takviye kuvvet olarak yararlanılmış, bir kısmı da madenlerde muhafızlık veya duvar ustalığı yapmışlardır. ${ }^{6}$ Önceleri çobanlıkla uğraşırken daha sonra bir dönemin nakliyecisi ve tüccarları olmuşlardır. ${ }^{7}$ Ticaretle uğraşanların yanı sıra terzi, nakkaş, kuyumcu gibi meslek gruplarında yer alan Ulahlar da vardır. ${ }^{8}$ Osmanlılar, Balkanları fethe başladığında karşılaştıkları halklardan biri de voyvoda adı verilen yerel önderler tarafindan idare edilen Ulahlar olmuştur. ${ }^{9}$ Yıldırım Bayezid döneminde yapılan anlaşma ile Ulahlara Bizans döneminde sahip oldukları haklar tanınmış, ${ }^{10}$ Çelebi Mehmet döneminde ise Osmanlı Devleti'ne haraç ödemeleri ve bazı Eflak gençlerinin rehin olarak İstanbul'a götürülmesi hususlarını içeren bir antlaşma imzalanmıştır. ${ }^{11}$ Osmanlı yönetimince serhatlara yerleştirilen Ulahlar orduda yardımcı birliklere alınmışlar ve kendilerine savaşta ve barışta çeşitli görevler verilmiştir. XVI. yüzyıldaki tahrir kayıtlarında diğer unsurlar gibi kayıt altına alınmışlar ve bir takım vergilerden muaf tutulmuşlardır. ${ }^{12} \mathrm{Bu}$ makalede Sultan II. Abdülhamid döneminde Ulahların istihdamına yönelik çalışmalar ve bu dönem içerisinde tutulmaya başlanan Sicill-i Ahvâl ${ }^{13}$ kayıtlarında yer alan Ulah memurlar hakkında bilgi verilecektir.

\section{Makedonya Meselesi ve Ulahlar}

1865'lerde ortaya çıkan Apostol Margarit adlı Ulah, XIX. yüzyılın son çeyreğinde siyasi ortamdan da yararlanarak propaganda çalışmalarına hız vermiştir. XIII. yüzyılda Makedonya bölgesindeki Bulgar İmparatorluğu'nda Rumen asıllı hükümdarların bulunduğunu ileri sürerek yeniden bir Ulah Devleti kurmayı ve Makedonya'yı onun sınırları içine almayı tasarlamıştır. ${ }^{14}$ Makedonyalı bir Ulah olan Margarit, Ulahların Yunan (Rum) kültürüne karşı başlattı̆̆ mücadeleyi yönetmiş, ${ }^{15}$ Manastır'daki Ulah mektepleri 1896 yılına kadar onun tarafından idare edilmiştir. 1878 yılından sonra Ulah mekteplerinin eğitiminden sorumlu tek kişi olmuştur. ${ }^{16}$

\footnotetext{
${ }^{4}$ Celal Nuri İleri, "Bulgar ve Pomak”, Ankara Üniversitesi Dil ve Tarih-Coğrafya Fakültesi Dergisi, 53, 2 (2013), s. 422.

${ }^{5}$ Birecikli, s. 940 .

${ }^{6}$ Noel Malcolm, Kosova Balkanları Anlamak İçin, Türkçesi: Özden Arıkan, Sabah Kitapları, İstanbul 1999, s. $256-$ 257.

${ }^{7}$ Harp Akademileri Komutanlığı, Makedonya, Harp Akademileri Basımevi, İstanbul 1992, s. 77; Dimo N. Dimçev, “Osmanlı Döneminde Türk-Ulah Münasebetleri”, XIII. Türk Tarih Kongresi 4-8 Ekim 1999, Cilt: 3, Kısım: I, Türk Tarih Kurumu, Ankara 2002, s. 128.

${ }^{8}$ Lucy M.J. Garnett, Türkiye’nin Kadınları ve Folklorik Özellikleri, Oğlak Bilimsel Kitaplar, İstanbul 2009, s. 17 18.

${ }^{9}$ Andrew Baruch Wachtel, Dünya Tarihinde Balkanlar, Çeviren: Ali Cevat Akkoyunlu, Doğan Kitap, İstanbul 2009, s. 51.

${ }^{10}$ Dimçev, s. 127.

${ }^{11}$ Köseoğlu, s. 38.

12 Birecikli, s. 944.

${ }^{13}$ Sicill-i Ahvâl Defterleri, 1879-1909 yılları arasında devlet hizmetinde bulunan memurların sicil kayıtlarını ihtiva eden, yakın dönem Osmanlı biyografi yazımında başvurulan en önemli kaynaktır. Sultan II. Abdülhamid devrinde görev yapan memurların görevleri dönemindeki gelişimi takip etmek amacıyla hazırlanmıştır. (Gülden Sarıyıldız, "Sicill-i Ahvâl Defterleri", Türkiye Diyanet Vakfi İslâm Ansiklopedisi, Türkiye Diyanet Vakfı Yayınları, C. 37, İstanbul 2009, s. 135).

${ }^{14}$ Aram Andonyan, Balkan Savaşı, Çeviren: Zaven Biberyan, Aras Yayıncılık, İstanbul 1999, s. 104.

${ }^{15}$ Birecikli, s. 957.

${ }^{16}$ Köseoğlu, s. 83.
} 
Berlin Kongresi'nden sonra ortaya çıkan Makedonya Sorunu bölgede 100 bin civarında $^{17}$ nüfusa sahip olan Ulahları da kapsamaktaydı. Bunda Romanya hükümetinin 1878 sonrasında Ulahlara millet statüsünü kazandırma çabasının da etkisi olmuştur. ${ }^{18}$ Balkan milletlerinin Makedonya'ya sahip olma mücadelesi verdiği bu dönemde Ulahları köken olarak kendilerine yakın gören Romanya yönetimi hem bu yakınlığın etkisi hem de Makedonya'da nüfuzunu arttırma düşüncesiyle onların hamiliğini yapmış, Rum ve Bulgarların bölgede Ulahlara karşı izledikleri politikalara karşı onları desteklemiştir. ${ }^{19}$ Hükümet bütçesine Rumeli Ulahlarının himaye ve kalkınması için yardım amacıyla önemli tutarda ödenek koymuş, Romanya ileri gelenlerinden tanınmış bir kişi olan İstirio Domo'yu "Rumeli Ulahlarına Yardım Teşkilatı" genel kâtipliğine tayin etmiştir. ${ }^{20}$ Patrikhane ile mücadelelerinde Ulahlardan yana tavır alan Sadrazam Ferid Paşa'ya Romanya Devleti tarafından en büyük şeref nişanı verilmiştir. ${ }^{21}$ Osmanlı yönetimi ile Ulahlar konusunda daima irtibat halinde olan Romanya hükümeti bir taraftan kendi kamuoyunda Ulahların sıkıntılarını gündemde tutarken diğer taraftan da onların maruz kaldığı sıkıntıların çözümü için Osmanlı nezdinde teşebbüslerde bulunmuştur. $\mathrm{Bu}$ yöndeki girişimlerini XX. yüzyıl başlarında arttıran Romanya yönetiminin talepleri arasında bu çalışmanın konusunu oluşturan Ulahların istihdamı meselesi de yer almıştır. ${ }^{22}$

\section{Ulahların İstihdamına Yönelik Faaliyetler}

Sultan Abdülhamid dönemi öncesinde Ulahlardan istihdam edilen kişiler olmuştur. Örneğin 1828 yılında Manastır'da doğan Yorgi Dosyos Paşa, 1849 yılında Beylerbeyi Hastanesinde tabip olarak göreve başlamıştır. Daha sonra II. Abdülhamid dönemine kadar geçen süreçte Askeri, Maltepe, Haydarpaşa, Kuleli ve Bab-1 Zabtiye Hastaneleriyle Mabeyn-i Hümayun Eczanesinde görev yapmıştır. ${ }^{23}$ Sultan Abdülmecid döneminde Paris'te bulunan Ulah mültecilerin Osmanlı Devleti'ne hizmet etmek istediklerini İstanbul'a ilettikleri bilinmektedir. ${ }^{24}$ Sultan Abdülhamid döneminde özellikle de XX. yüzyıl başlarında Ulahların istihdamı yönünde girişimler dikkat çekmektedir. 1902 y1lı sonlarında Rumeli vilayetlerine gönderilen telgrafta bölgede yaşayan Ulah, Bulgar ve Sirplardan sahib-i namus ve itibar olup İstanbul'da silahşorluk ve benzeri hizmetlerde istihdama elverişli olanların bildirilmesi istenmiştir. ${ }^{25} \mathrm{Bu}$ sıralarda Ulahların Osmanlı mekteplerine ve devlet hizmetine kabul edilmek, nüfus tezkirelerinde milliyetlerinin açıkça belirtilmesi ve bulundukları yerde muhtar olabilmeleri yönünde talepleri olmuştur. ${ }^{26}$ Kısa bir süre sonra Bulgarların yaşadığı yerlere liyakatli ve işinde başarılı Rum ve Ulahlardan dört polis ve bir komiser ataması yapılmıştır. Bunun üzerine Romanya elçisi Babıâli’ye teşekkürlerini bildirmiştir. ${ }^{27}$ Romanya elçisi Lahovary, Ulahlardan polis ve komiser ataması yapılmasının ardından Sultan Abdülhamid ile görüşür. Bu görüşmede Osmanlı okullarında eğitim görmüş, tarafsız olan Osmanlı tebaası Ulahlardan bir kısmının devlet hizmetinde istihdam edilmesi konuşulmuş ve Sultan elçiden bu yönde bir çalışma yapmasını istemiştir. Bunun üzerine Lahovary, Yıldız'a yaşları 23 ile 55

\footnotetext{
${ }^{17}$ Stefanos Yerasimos, Milliyetler ve Sinırlar Balkanlar, Kafkasya ve Ortadoğu, İletişim Yayınları, İstanbul 1994, s. 65. Rumeli'de çoğunluğu Manastır vilayetinde yaşayan 150 bin nüfuslu Sarı Kaçanlar ve Yanya, Manastır, Selanik ve Kosova'da yaşayan 200 bin kişilik Karakaçanlar olmak üzere iki Ulah topluluğu vardı. (Tahsin Uzer, Makedonya Eşkıyalık Tarihi ve Son Osmanlı Yönetimi, Türk Tarih Kurumu Yayınları, Ankara 1999, s. 204).

${ }^{18}$ Birecikli, s. 944.

${ }^{19}$ Köseoğlu, s. 70.

${ }^{20}$ Uzer, s. 204; Birecikli, s. 955.

${ }^{21}$ Birecikli, s. 955; Andonyan, s. 105.

${ }^{22}$ Köseoğlu, s. 70.

${ }^{23}$ Başbakanlık Osmanlı Arşivi (BOA), Dahiliye Nezâreti Sicill-i Ahvâl Defterleri (DH.SAID.d), Nr: 76/236.

${ }^{24}$ BOA, Sadaret Mektubî Kalemi Umum Vilâyât (A.MKT.UM.), Nr: 145/30, 25 Muharrem 1270 (28 Ekim 1853).

${ }^{25}$ BOA, Rumeli Müfettişliği Sadâret (TFR.I.A.), Nr: 1/74, 20 Ramazan 1320 (21 Aralık 1902).

${ }^{26}$ BOA, Babıali Evrak Odası (BEO), Nr: 2005/150335, 21 Zilkade 1320 (19 Şubat 1903).

${ }^{27}$ BOA, Yıldız Sadâret Hususî (Y.A.HUS.), Nr: 444/40, 19 Zilhicce 1320 (19 Mart 1903).
} 
arasında değişen 36 kişilik bir liste sunmuştur. Listede yer alan Ulahlar hakkındaki bilgiler aşağıdaki tabloda gösterilmiştir. ${ }^{28}$

Tablo: Osmanlı’da İstihdam Edilmek Üzere Belirlenen Ulahlar

\begin{tabular}{|c|c|c|c|c|c|c|}
\hline Adı & Baba Adı & Yaşı & Memuriyeti & $\begin{array}{l}\text { Doğum } \\
\text { Yeri }\end{array}$ & $\begin{array}{l}\text { Yaşadığı } \\
\text { Yer }\end{array}$ & $\begin{array}{l}\text { Rütbe, Diploma } \\
\text { ve Bulunduğu } \\
\text { Memuriyet }\end{array}$ \\
\hline $\begin{array}{l}\text { Perekli } \\
\text { Efendi }\end{array}$ & Poçara & 33 & $\begin{array}{l}\text { Manastır'da } \\
\text { Tabip ve } \\
\text { Muallim }\end{array}$ & $\begin{array}{l}\text { Pirlepe } \\
\text { (Manastır) }\end{array}$ & Manastır & $\begin{array}{l}\text { İstanbul Tıbbiye } \\
\text { Mektebinden } \\
\text { mezun olmuştur. } \\
\text { Manastır Ulah } \\
\text { Mektebi } \\
\text { müdürlüğü } \\
\text { yapmıştır. }\end{array}$ \\
\hline $\begin{array}{l}\text { Pandeli } \\
\text { Efendi }\end{array}$ & Maşo & 33 & $\begin{array}{l}\text { Köprülü'de } \\
\text { Belediye } \\
\text { Tabibi ve } \\
\text { Muallim }\end{array}$ & $\begin{array}{l}\text { Köprülü } \\
\text { (Kosova) }\end{array}$ & Köprülü & $\begin{array}{l}\text { Manastır Ulah } \\
\text { Mektebinden } \\
\text { mezun olmuştur. }\end{array}$ \\
\hline $\begin{array}{l}\text { Kotula } \\
\text { Efendi }\end{array}$ & Adam & 36 & $\begin{array}{l}\text { İstanbul'da } \\
\text { Dava Vekili }\end{array}$ & $\begin{array}{l}\text { Ulah } \\
\text { Glisora } \\
\text { (Manastır) }\end{array}$ & İstanbul & $\begin{array}{l}\text { İstanbul Hukuk } \\
\text { Mektebinden } \\
\text { mezun olmuştur. } \\
\text { Pasaport } \\
\text { Memurluğu ve } \\
\text { Kaymakam } \\
\text { Yardımcılığı } \\
\text { yapmıştır. }\end{array}$ \\
\hline $\begin{array}{l}\text { Simon } \\
\text { Efendi }\end{array}$ & Berberi & 37 & $\begin{array}{l}\text { Manastır'da } \\
\text { Tabip, } \\
\text { Kesriye } \\
\text { Kazas1 } \\
\text { Belediye } \\
\text { Tabibi }\end{array}$ & $\begin{array}{l}\text { Ulah } \\
\text { Glisora } \\
\text { (Manastır) }\end{array}$ & Kesriye & $\begin{array}{l}\text { Ulah Mektebi ve } \\
\text { Tibbiye } \\
\text { Mektebinde } \\
\text { eğitim } \\
\text { görmüştür. }\end{array}$ \\
\hline $\begin{array}{l}\text { Yovan } \\
\text { Efendi }\end{array}$ & Lala & 36 & Dava Vekili & Manastır & Manastır & $\begin{array}{l}\text { Manastır } \\
\text { Osmanlı } \\
\text { Mektebinden } \\
\text { mezun olmuştur. } \\
\text { Eski Manastır } \\
\text { Meclisi azasıdır. }\end{array}$ \\
\hline $\begin{array}{l}\text { Kostantin } \\
\text { Efendi }\end{array}$ & Meta & 29 & $\begin{array}{l}\text { Ulah } \\
\text { Muallimi ve } \\
\text { Dava Vekili }\end{array}$ & $\begin{array}{l}\text { Molovişste } \\
\text { (Manastır) }\end{array}$ & Manastır & $\begin{array}{l}\text { Ulah Mektebi ve } \\
\text { İstanbul Hukuk } \\
\text { Mektebinden } \\
\text { mezun olmuștur. }\end{array}$ \\
\hline $\begin{array}{l}\text { Zisi } \\
\text { Efendi }\end{array}$ & Papa Tanaş & 45 & $\begin{array}{l}\text { Grebene'de } \\
\text { Tabip ve Ulah } \\
\text { Muallimi }\end{array}$ & $\begin{array}{l}\text { Balise } \\
\text { (Yanya) }\end{array}$ & $\begin{array}{l}\text { Grebene } \\
\text { (Yanya) }\end{array}$ & $\begin{array}{l}\text { Manastır Ulah } \\
\text { Mektebi ve } \\
\text { İstanbul Tibbiye }\end{array}$ \\
\hline
\end{tabular}

${ }^{28}$ BOA, İâde Hususî (İ.HUS), Nr: 102/123, 27 Zilkade 1320 (25 Şubat 1903); Yıldız Perakende Elçilik, Şehbenderlik ve Ataşemiliterlik (Y.PRK. EŞA), Nr: 42/16, 27 Zilkade 1320 (25 Şubat 1903); Y.A.HUS, Nr: 444/4, 15 Zilhicce 1320 (15 Mart 1903). 
Mucize ÜNLÜ-Ahmet YADI

\begin{tabular}{|c|c|c|c|c|c|c|c|}
\hline \multirow{9}{*}{$\begin{array}{l}\substack{\text { y } \\
\text { HISTORY } \\
\text { STUDIES }} \\
\mathbf{2 7 1}\end{array}$} & & & & & & & $\begin{array}{l}\text { Mektebinden } \\
\text { mezun olmuştur. }\end{array}$ \\
\hline & $\begin{array}{l}\text { Esteryo } \\
\text { Efendi }\end{array}$ & Çubuki & 35 & Mühendis & $\begin{array}{l}\text { Karaferye } \\
\text { (Selanik) }\end{array}$ & Manastır & $\begin{array}{l}\text { Ulah } \\
\text { Mektebinden } \\
\text { mezun olmusstur. } \\
\text { Mühendislik } \\
\text { yapmaktadır. }\end{array}$ \\
\hline & $\begin{array}{l}\text { Vangel } \\
\text { Efendi }\end{array}$ & Petresko & 50 & $\begin{array}{l}\text { Ulah } \\
\text { Muallimi }\end{array}$ & $\begin{array}{l}\text { Hroşova } \\
\text { (Manastır) }\end{array}$ & $\begin{array}{l}\text { Hroşova } \\
\text { (Manastır) }\end{array}$ & $\begin{array}{l}\text { Ulah } \\
\text { Mektebinden } \\
\text { mezun olmuştur. } \\
\text { Mekteb-i } \\
\text { Sultanide eğitim } \\
\text { görmektedir. } \\
\text { Telgraf } \\
\text { memurluğu } \\
\text { yapmıştır. }\end{array}$ \\
\hline & $\begin{array}{l}\text { Grigor } \\
\text { Efendi }\end{array}$ & Todorosko & 35 & $\begin{array}{l}\text { Ulah } \\
\text { Muallimi }\end{array}$ & $\begin{array}{l}\text { Resne } \\
\text { (Manastır) }\end{array}$ & $\begin{array}{l}\text { Katerina } \\
\text { (Manastır) }\end{array}$ & $\begin{array}{l}\text { Mezheb Mektebi } \\
\text { ve Ulah } \\
\text { Mektebinden } \\
\text { mezun olmuştur. }\end{array}$ \\
\hline & $\begin{array}{l}\text { Nikola } \\
\text { Efendi }\end{array}$ & Papa Hacı & 30 & $\begin{array}{l}\text { Ulah } \\
\text { Muallimi }\end{array}$ & $\begin{array}{l}\text { Udala } \\
\text { (Manastır) }\end{array}$ & Selanik & $\begin{array}{l}\text { Ulah Mektebi ve } \\
\text { Mekteb-i } \\
\text { Sultaniden } \\
\text { mezun olmuştur. }\end{array}$ \\
\hline & $\begin{array}{l}\text { Yorgi } \\
\text { Efendi }\end{array}$ & Çuyutka & 38 & $\begin{array}{l}\text { Türkçe Lisan } \\
\text { Muallimi }\end{array}$ & $\begin{array}{l}\text { Karaferye } \\
\text { (Selanik) }\end{array}$ & Selanik & $\begin{array}{l}\text { Ulah } \\
\text { Mektebinden } \\
\text { mezun olduktan } \\
\text { sonra İstanbul } \\
\text { Hukuk } \\
\text { Mektebi'ne } \\
\text { devam etmiştir. } \\
\text { Eski Pasaport } \\
\text { memurudur. }\end{array}$ \\
\hline & $\begin{array}{l}\text { Panil } \\
\text { Efendi }\end{array}$ & Hacı Goga & 32 & $\begin{array}{l}\text { Ulah } \\
\text { Muallimi }\end{array}$ & $\begin{array}{l}\text { Karaferye } \\
\text { (Selanik) }\end{array}$ & Selanik & $\begin{array}{l}\text { Ulah } \\
\text { Mektebinden } \\
\text { mezun olmuştur. } \\
\text { Dava Vekilliği } \\
\text { ve Pasaport } \\
\text { Memurluğu } \\
\text { yapmiştır. }\end{array}$ \\
\hline & $\begin{array}{l}\text { Yani } \\
\text { Efendi }\end{array}$ & Papa Hacı & 36 & $\begin{array}{l}\text { Grebene'de } \\
\text { Pasaport } \\
\text { Memuru }\end{array}$ & $\begin{array}{l}\text { Udala } \\
\text { (Manastır) }\end{array}$ & $\begin{array}{l}\text { Grebene } \\
\text { (Yanya) }\end{array}$ & $\begin{array}{l}\text { Manastır Ulah } \\
\text { Mektebinden } \\
\text { mezun olmuş ve } \\
\text { bu mektepte } \\
\text { muallimlik } \\
\text { yapmiştır. }\end{array}$ \\
\hline & $\begin{array}{l}\text { Papa } \\
\text { Efendi }\end{array}$ & Goga & 25 & $\begin{array}{l}\text { Mektepte } \\
\text { öğrenimine } \\
\text { devam }\end{array}$ & $\begin{array}{l}\text { Garbeş } \\
\text { (Manastır) }\end{array}$ & İstanbul & $\begin{array}{l}\text { Manastır Ulah } \\
\text { Mektebinden } \\
\text { mezun olmuştur. }\end{array}$ \\
\hline
\end{tabular}


II. Abdülhamid Döneminde Ulahların İstihdamına Dair

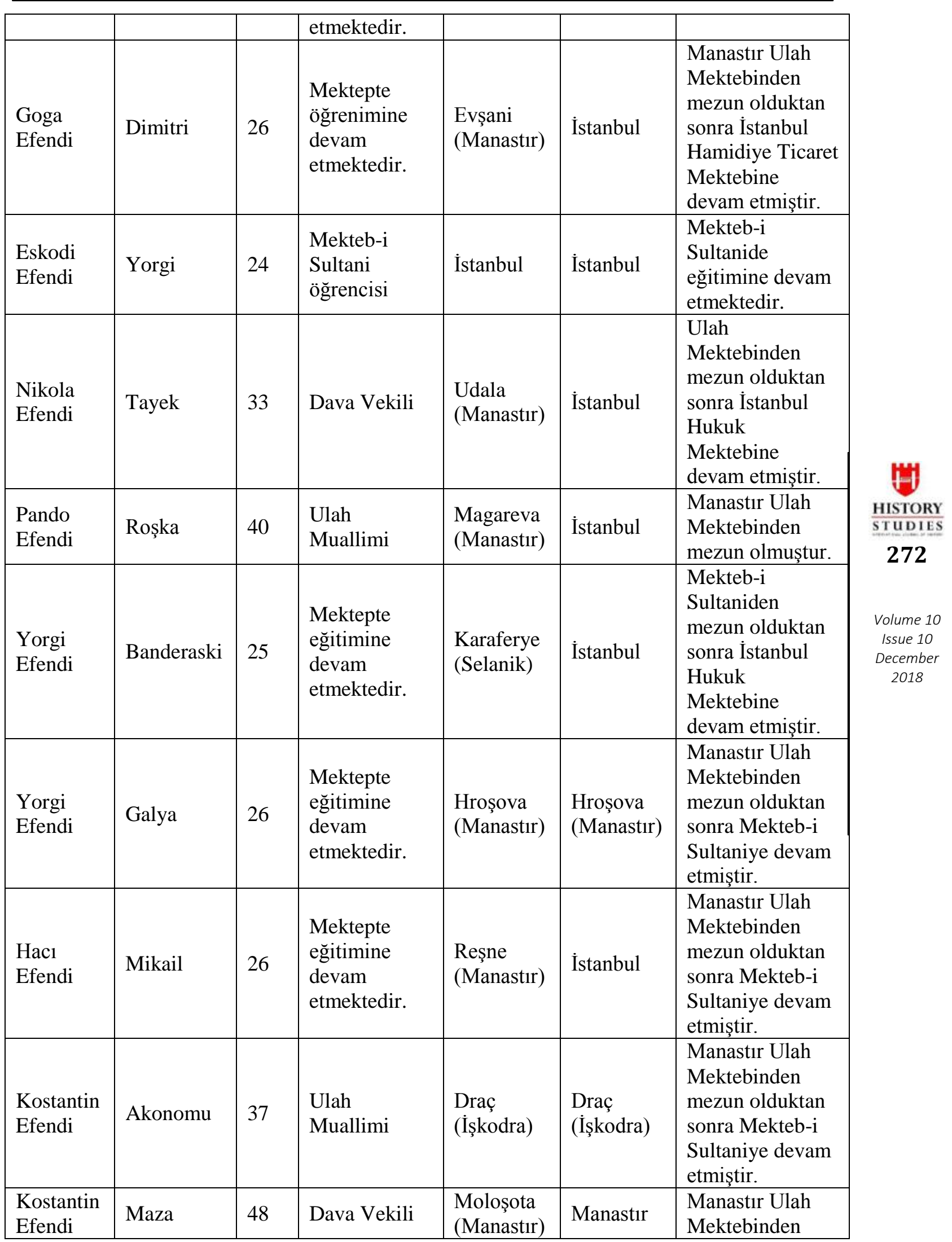


Mucize ÜNLÜ - Ahmet YADi

\begin{tabular}{|c|c|c|c|c|c|c|}
\hline & & & & & & $\begin{array}{l}\text { mezun olmuştur. } \\
\text { Eski Manastır } \\
\text { Meclisi azasıdır. }\end{array}$ \\
\hline Pendeli & Hirmitovic & 45 & Tabip & Manastır & Manastır & $\begin{array}{l}\text { Manastır Ulah } \\
\text { Mektebinden ve } \\
\text { İstanbul Hukuk } \\
\text { Mektebinden } \\
\text { mezun olmuştur. }\end{array}$ \\
\hline $\begin{array}{l}\text { Honder } \\
\text { Veron } \\
\text { Efendi }\end{array}$ & - & 48 & $\begin{array}{l}\text { Ulah } \\
\text { Muallimi }\end{array}$ & $\begin{array}{l}\text { Samarina } \\
\text { (Manastır) }\end{array}$ & Manastır & $\begin{array}{l}\text { Ulah } \\
\text { Mektebinden } \\
\text { mezun olmuştur. }\end{array}$ \\
\hline $\begin{array}{l}\text { Papa } \\
\text { Kosti } \\
\text { Efendi }\end{array}$ & - & 23 & $\begin{array}{l}\text { Ulah } \\
\text { Muallimi }\end{array}$ & $\begin{array}{l}\text { Samarina } \\
\text { (Manastır) }\end{array}$ & İstanbul & $\begin{array}{l}\text { Mekteb-i } \\
\text { Sultaniden } \\
\text { mezun olmuştur. }\end{array}$ \\
\hline $\begin{array}{l}\text { Nikolaki } \\
\text { Efendi }\end{array}$ & Boya & 34 & $\begin{array}{l}\text { Ulah } \\
\text { Muallimi }\end{array}$ & $\begin{array}{l}\text { Hroşova } \\
\text { (Manastır) }\end{array}$ & $\begin{array}{l}\text { Hroşova } \\
\text { (Manastır) }\end{array}$ & $\begin{array}{l}\text { Manastır Ulah } \\
\text { Mektebinden } \\
\text { mezun olmuştur. }\end{array}$ \\
\hline $\begin{array}{l}\text { Tanaş } \\
\text { Efendi }\end{array}$ & Kazata & 30 & $\begin{array}{l}\text { Hariciye } \\
\text { Nezaretinde } \\
\text { Memur }\end{array}$ & $\begin{array}{l}\text { Beyase } \\
\text { (Manastır) }\end{array}$ & İstanbul & $\begin{array}{l}\text { İstanbul Hukuk } \\
\text { Mektebinden } \\
\text { mezun olmuştur. }\end{array}$ \\
\hline $\begin{array}{l}\text { Taşko } \\
\text { Efendi }\end{array}$ & Poçara & 31 & $\begin{array}{l}\text { Eczac1 ve } \\
\text { Kimyager }\end{array}$ & $\begin{array}{l}\text { Pirlepe } \\
\text { (Manastır) }\end{array}$ & Manastır & $\begin{array}{l}\text { İstanbul Tibbiye } \\
\text { Mektebinden } \\
\text { mezun olmuştur. }\end{array}$ \\
\hline $\begin{array}{l}\text { Zisi } \\
\text { Efendi }\end{array}$ & Baba Yani & 25 & $\begin{array}{l}\text { Ulah } \\
\text { Muallimi }\end{array}$ & $\begin{array}{l}\text { Katerina } \\
\text { (Selanik) }\end{array}$ & $\begin{array}{l}\text { Katerina } \\
\text { (Manastır) }\end{array}$ & $\begin{array}{l}\text { Manastır Ulah } \\
\text { Mektebinden } \\
\text { mezun olmuştur. }\end{array}$ \\
\hline $\begin{array}{l}\text { Apostol } \\
\text { Efendi }\end{array}$ & Cinya & 35 & $\begin{array}{l}\text { Polis } \\
\text { Komiseri (13 } \\
\text { y1ldır) }\end{array}$ & $\begin{array}{l}\text { Ulah } \\
\text { Glisora } \\
\text { (Manastır) }\end{array}$ & İstanbul & $\begin{array}{l}\text { Manastır Ulah } \\
\text { Mektebinden } \\
\text { mezun olmuştur. } \\
\text { Rütbe-i Salise'yi } \\
\text { haizdir. Hizmeti } \\
\text { takdir } \\
\text { edilmektedir. }\end{array}$ \\
\hline $\begin{array}{l}\text { Esteryo } \\
\text { Efendi }\end{array}$ & Simisko & 55 & $\begin{array}{l}\text { Ulah } \\
\text { Muallimi }\end{array}$ & $\begin{array}{l}\text { Hroşova } \\
\text { (Manastır) }\end{array}$ & Manastır & $\begin{array}{l}\text { Manastır Ulah } \\
\text { Mektebinden } \\
\text { mezun olmuştur. }\end{array}$ \\
\hline $\begin{array}{l}\text { Oto } \\
\text { Efendi }\end{array}$ & Hristo & 30 & $\begin{array}{l}\text { Mektepte } \\
\text { eğitimine } \\
\text { devam } \\
\text { etmektedir. }\end{array}$ & Manastır & İstanbul & $\begin{array}{l}\text { Manastır Ulah } \\
\text { Mektebinden } \\
\text { mezun olmuştur. }\end{array}$ \\
\hline $\begin{array}{l}\text { İstano } \\
\text { Efendi }\end{array}$ & Mikail & 29 & $\begin{array}{l}\text { Mektepte } \\
\text { eğitimine } \\
\text { devam } \\
\text { etmektedir. }\end{array}$ & Manastır & İstanbul & $\begin{array}{l}\text { Manastır Ulah } \\
\text { Mektebinden } \\
\text { mezun olmuştur. }\end{array}$ \\
\hline $\begin{array}{l}\text { Yovan } \\
\text { Efendi }\end{array}$ & Arçatoyano & 25 & $\begin{array}{l}\text { Mektepte } \\
\text { eğitimine } \\
\text { devam } \\
\text { etmektedir. }\end{array}$ & Manastır & İstanbul & $\begin{array}{l}\text { Manastır Ulah } \\
\text { Mektebinden } \\
\text { mezun olmuştur. }\end{array}$ \\
\hline
\end{tabular}


Tablodan anlaşılacağı üzere listede yer alan kişiler Selanik, Manastır, Kosova, Yanya ve İşkodra vilayetleri dâhilinde ikamet etmektedirler. Çoğu Manastır'da olmak üzere ilköğrenimlerini Ulah mekteplerinde tamamladıktan sonra İstanbul'da Osmanlı mekteplerine devam ederek diploma almış, Türkçe, Ulahça, Fransızca, Rumca, Sırpça, Bulgarca ve Arnavutça gibi lisanlara hâkim kişilerdir. Tabip, Muallim, Dava Vekili, Mühendis, Pasaport Memuru, Polis, Eczacı, Kimyager gibi meslek gruplarındandırlar. Dokuzu İstanbul'da Sultani, Hukuk ve Hamidiye Ticaret Mektebi gibi okullarda eğitimine devam etmektedir.

Listenin Padişaha sunulmasından sonra Meclis-i Vükelâda Ulahların niteliklerine göre uygun yerlerde istihdam edilmeleri yönünde karar alınmış ve Rumeli Müfettişliğine bu yönde emir gönderilmiştir. ${ }^{29} \mathrm{Bu}$ emir üzerine Müfettiş Hüseyin Hilmi Paşa, Müfettişliğin bunun için yetkisinin olmadığını belirterek listede yer alan Hukuk Mektebinden mezun kişilerin Adliye Nezareti tarafindan atamalarının yapılması gerektiğini İstanbul'a bildirmiştir. ${ }^{30}$ Kosova Valiliği ise vilayet dâhilinde yakın zamanda gayrimüslimlerden yeteri kadar jandarma ve polis istihdam edildiğini, belirtilen kişiler için uygun görevlerde boş yer olmadığını belirtmiştir. ${ }^{31}$ Birkaç ay sonra Romanya elçisi sunduğu listedeki kişilerden altısının Mabeyn-i Hümâyûn'da istihdam edilmesini talep etmiştir. İstihdam edilmesini istediği kişiler Dava Vekili Kostantin, Tabip Pandeli, Tabip Perekli, Muallim Papa Kosti, Muallim Panil ve Goga Efendilerdir. ${ }^{32}$

1905 yılının ilk aylarında Romanya yönetimi Ulahların sadakatine ${ }^{33}$ dikkat çekerek, Rum ve Bulgar vatandaşların yararlandığı hak ve ayrıcalıklardan onların da yararlanması gerektiğini belirtmiş ve Ulahların ikamet ettikleri kasaba, nahiye ve köylerde Rum ve Bulgarlardan ayrı olmak üzere kendi muhtarlarını seçebilmelerinin temin edilmesini istemiştir. Ayrıca vilayet, liva ve kazalarda bulunan meclislerde Ulahlardan birer aza bulundurulması gerektiğini de ifade etmiştir. ${ }^{34}$ Bir süre sonra 22 Mayıs 1905 tarihli irade ile Osmanlı Devleti'nin Ulahları ayrı bir millet olarak kabul ettiği resmiyete dökülmüştür. ${ }^{35}$ Romanya hükümeti Türkiye ile olan iyi ilişkilerinden yararlanarak Ulahları Helenizm'den ayırmanın Osmanlı için daha yararlı olacağına Babıâli’yi inandırmıştır. Ulahları Rum unsurdan ayırıp ayrı cemaat haline getiren fermanın elde edilmesinde Romanya'nın İstanbul elçisinin büyük rolü olmuştur. ${ }^{36}$ Ferman ile

${ }^{29}$ BOA, Meclis-i Vükelâ Mazbatalarl (MV), Nr: 105/78, 6 Zilhicce 1320 (6 Mart 1903); Mucize Ünlü, "II. Abdülhamid Döneminde Ulahlar”, Türk-İslâm Medeniyeti Akademik Araştırmalar Dergisi, Sayı 7/Kış, Konya 2009, s. 157.

${ }^{30}$ BOA, Dahiliye Nezâreti Mektubî Kalemi (DH.MKT), Nr: 670/56, 22 Zilhicce 1320 (22 Mart 1903).

31 BOA, Rumeli Müfettişliği Makamat (TFR.I.MKM), Nr: 2/103, 28 Zilhicce 1320 (28 Mart 1903); BEO, Nr: 2065/154865, 13 Safer 1321 (11 Mayıs 1903).

${ }^{32}$ BOA, Y.A.HUS., Nr: 451/82, 8 Rebiülahir 1321 (4 Temmuz 1903). Bu kişilerin talep edilen yerde istihdam edilip edilmediği konusunda bir bilgiye ulaşılamamıştır.

${ }^{33}$ Osmanlı Devleti'ne sadakatini çeşitli vesilelerle ifade eden Ulahlar, 1895 yılında Bükreş’te bulunan Türk Sefareti önünde bu yönde gösteriler düzenlemişlerdir. Aynı tarihte Romanya'da bulunan Makedonya Ulahları da sadakatlerini dile getiren telgraf çekmişlerdir. (Köseoğlu, s. 39). Yunan hudut kumandanı Neşet Paşa'nın Ağustos 1898 'de bölgedeki teftişi sonrasında hazırladığı raporunda Alasonya'dan Maçova'ya kadar olan yerlerin önemli kısmının Ulahlarla meskûn olduğu ve bunların padişaha çok bağlı oldukları vurgulanmıştır. (Ünlü, s. 155). Ulah Edebiyatı'nın önemli isimlerinden Constantin Belemace (1848-1932/Manastır) tarafından Sultan Abdülhamid için yazılan ve 1903 yılında Lumina (Işık) dergisinin birinci sayısında yayınlanan şiir için bkz. EK II. (Bu şiir Araştırmacı-Gazeteci Eyüp SALİH (Makedonya) tarafından 22-24 Ekim 2018 tarihlerinde İstanbul'da gerçekleştirilen Vefatının 100. Yılında Sultan II. Abdülhamid ve Dönemi Uluslararası Kongresinde sunulan "Sultan II. Abdülhamid Döneminde Makedonya'da Çıkan Gazete ve Dergiler" başlıklı tebliğde yer almıştır. Şiirden bizi haberdar eden ve tebliğini bizimle paylaşan Eyüp SALİH Bey'e teşekkür ederiz).

${ }^{34}$ BOA, BEO, Nr: 2530/189707, 13 Muharrem 1323 (20 Mart 1905).

${ }^{35}$ BOA, Irâde Dâhiliye (İ.DH.), Nr: 1434/10, 17 Rebiülevvel 1323 (22 Mayıs 1905).

${ }^{36}$ Andonyan, s. 105. Büyük devletler Babıâli'nin Makedonya'daki Ulahları ayrı bir unsur olarak tanımasından Hıristiyan bir toplum olmalarına rağmen- yeni sorunlara yol açacağı düşüncesiyle memnun olmamışlardır. (Sacit 
mezhep işlerinde yine Rum Patrikhanesi'ne bağlı kalmışlar ancak Osmanlı vatandaşı olan Rum, Bulgar ve Sırplar gibi ayrı bir cemaat olarak tanınmışlardır. Bulundukları köy ve mahallelerde muhtar seçilebilecekler, idare meclislerine aza olabileceklerdir. ${ }^{37}$ Nitekim Selanik valisi Rumeli Müfettişliğine gönderdiği yazıda vilayet nizamnamesine göre her sınıftan muhtar tayin edilebileceğini ve nüfus olarak muhtar seçimine elverişli olan yerlerde Ulahlardan muhtar seçilmesinin kanuna uygun olduğunu ifade etmiştir. ${ }^{38} \mathrm{Bu}$ doğrultuda yapılan seçimler sonucunda Ulahlardan muhtar çıkması diğer cemaatlerin şikâyetlerine neden olmuşsa da Rumeli Müfettişi Hüseyin Hilmi Paşa bunda bir mahzur olmadığını belirterek hukuka riayet edileceğini dile getirmiştir. ${ }^{39}$ Bir süre sonra Rumeli Müfettişliğine muhtar seçilme ve mecliste aza bulundurma hakkını elde eden Ulahların, yaşadıkları yerlerdeki nüfus tahrir komisyonlarına aza olarak tayin edilebileceği bildirilmiştir. ${ }^{40}$

Aza tayini ilk olarak Manastır kazasında oluşturulan nüfus tahrir komisyonuna yapılmıştır. ${ }^{41}$ Ardından Sadaret, nüfus tahririnde karışıklığa meydan vermemek adına Yanya'daki nüfus komisyonuna da bir Ulah'ın aza olarak tayin edilmesini istemiştir. Bahsedilen karışıklık Ulahların bu bölgelerde nüfus sayımında Rum olarak kaydedilmesinden ileri gelmekteydi. Bu sebeple Çevilevo, Maçova, Koniçe, Premedi kazalarıyla Yanya merkezinde bulunan Ulah köylerindeki nüfus tahrirlerinde bir Ulah azanın bulunmasının elzem olduğu belirtiliyordu. Ulahça konuşulan Zagora nahiyesinde dokuz köyde 7.500 ve Malkas ${ }^{42}$ nahiyesinde üç köyde 3.350 olmak üzere vilayette toplam 10.850 nüfus bulunmaktaydı. Ancak 500 nüfuslu Vose köyü halkı Ulah olduklarını beyan ederken diğer köyler Rum oldukları iddialarını sürdürmüşlerdir. ${ }^{43}$ Rumluk iddiasında bulunulan bölgelerde nüfus nizamnamesinin 62. maddesine göre nüfus komisyonlarına Ulah aza tayinine gerek görülmemiştir. Çok az nüfusu olan yerlere de Ulah aza tayin edilmesi diğerlerinin şikâyetine neden olabileceğinden Dâhiliye Nezareti, kesin emir gelinceye kadar yürürlükte olan kanununa göre hareket edilmesini bildirmiştir. ${ }^{44}$ Fakat Yanya' da oluşturulan altı komisyonun hiçbirine Ulahlardan aza tayin edilmemesi şikâyete sebep olmuş ve Babıâli durumun araştırılmasını istemiştir. Yanya valisi vilayette bir iki köyde çok az miktarda Ulah nüfus bulunmasından dolayı komisyona aza atamasının gerçekleştirilmediğini ifade etmiştir. ${ }^{45}$

Ulahların istihdam edildiği bir diğer görev de pasaport memurluğudur. Manastır ve Yanya'daki Yunan eşkıyasının takip edilmesi amacıyla Grebene'de Ulahlardan bir pasaport memuru bulundurulmaktaydı. Grebene Rum metropolitinin teşvikiyle bu memurluk bir süre için kaldırılmış ancak 1906 yılında yine eskisi gibi Grebene'de Ulah pasaport memurunun bulundurulması kararı alınmıştır. ${ }^{46}$

Kutlu, Milliyetçilik ve Emperyalizm Yüzyılında Balkanlar ve Osmanlı Devleti, İstanbul Bilgi Üniversitesi Yayınları, İstanbul 2007, s. 213).

${ }^{37}$ Ünlü, s. 157.

${ }^{38}$ BOA, Rumeli Müfettişliği Selanik (TFR.I.SL), Nr: 74/7307, 30 Rebiülevvel 1323 (4 Haziran 1905).

${ }^{39}$ BOA, BEO, Nr: 2606/195398, 20 Rebiülahir 1323 (24 Haziran 1905).

${ }^{40}$ BOA, BEO, Nr: 2652/198894, 27 Cemazielahir 1323 (29 Ağustos 1905).

${ }^{41}$ Ünlü, s. 158.

${ }^{42}$ Yanya'ya bağlı bir nahiyedir. (Nuri Akbayar, Osmanlı Yer Adları Sözlüğü, Tarih Vakfı Yurt Yayınları, 2. Baskı, İstanbul 2001, s. 112.)

${ }^{43}$ BOA, BEO, Nr: 2654/199037, 29 Cemazielahir 1323 (31 Ağustos 1905); Nr: 2658/199292, 2 Receb 1323 (2 Eylül 1905).

${ }^{44}$ BOA, BEO, Nr: 2667/199984, 17 Receb 1323 (17 Eylül 1905).

${ }^{45}$ BOA, BEO, Nr: 2674/200500, 25 Receb 1323 (25 Eylül 1905).

${ }^{46}$ BOA, BEO, Nr: 2767/207505, 1 Muharrem 1324 (25 Şubat 1906). 
II. Abdülhamid Döneminde Ulahların İstihdamına Dair

\section{Sicill-i Ahvâl Kayıtlarına Göre Ulah Memurlar ${ }^{47}$}

\section{Apostol Efendi}

1868 y1lında Manastır'ın Glisor köyünde doğan Apostol Efendi, Tüccar Dimitri'nin oğludur. Manastır Ulah Mektebinde eğitim görmüştür. Türkçe, Fransızca, Rumca ve Ulahça yazmakta, İtalyanca ve Bulgarca konuşmaktadır. 15 Ekim 1890'da 300 kuruş maaşla İstanbul Polis 2. bölüğü 8. çavuşluğunun 5. neferliğine atanmıştır. 8 Ağustos 1894 'te 500 kuruş maaşla 4 numaralı tertib-i haricî, 13 Mayıs 1899'da aynı maaşla 38 numaralı tertib-i cedid ve 13 Eylül 1899 'da 2. bölük 3. sınıf komiserliklerine nakledilmiştir. 23 Ağustos 1900'de 1.000 kuruş maaşla 19 numaralı sivil ser komiserliğine, 14 Ağustos 1909'da da 1.000 kuruş maaşla İstanbul Polis Komiserliğine atanmıştır.

Apostol Efendi’ye 1892-1904 yılları arasında Tahlisiye, Yunan Muharebesi, Gümüş İftihar, Hicaz Demir Yolları ve Gümüş Liyakat madalyaları takdim edilmiştir. 9 Eylül 1897'de Rütbe-i Rabia, 11 Eylül 1905'te ise Dördüncü Rütbeden Osmânî nişanı verilmiştir. Ayrıca 16 Aralık 1892'de Romanya tarafindan Servis Fidel Madalyası, 9 Ekim 1903'de yine Romanya tarafından Beşinci Rütbeden Kron de Romani ve 21 Eylül 1899'da Bulgaristan tarafindan Sivil adlı İstavroz ile taltif edilmiştir. Yunan Muharebesinde Tesalya'ya gitmesinden dolayı 150, Zabtiye Nezareti tarafından Selanik'e gönderildiğinde 11, Çanakkale'ye gönderildiğinde 4 lira harcırah ve Romanya'dan İstanbul'a gelmiş olan misafirlere tercümanlık göreviyle Mabeyn-i Hümayuna gönderildiğinde ise 500 kuruş atiyye verilmiştir. ${ }^{48}$

\section{Dimestoklu Penbeta Efendi}

1877'de Kesriye'nin Samarina köyünde doğmuştur. Nikola'nın oğludur. Doğduğu köyde ilk temel bilgileri öğrendikten sonra Manastır Mülkiye İdadisinden mezun olmuştur. Ardından Bükreş Darülfünunu hukuk kısmında öğrenim görmüştür. 5 Nisan 1904'te diplomasını aldıktan sonra yapılan imtihan sonucunda 1. sınıf dava vekili ruhsatnamesini almıştır. Türkçe, Fransızca, İtalyanca, Ulahça ve Rumca bilmektedir. 8 Kasım 1909'da 1.200 kuruş maaşla Kosova Bidayet Mahkemesi azalığına atanmıştır. ${ }^{49}$

\section{Dimitri Vilinos Efendi}

Tüccar Nikola'nın oğlu olan Dimitri Vilinos, 1885 'de Manastır'ın Tanolova köyünde doğmuştur. Doğduğu köydeki iptidaî mektebinde beş sene okuduktan sonra Manastır Ulah İdadi Mektebinde eğitim görmüştür. Türkçe, Ulahça, Bulgarca bilmektedir. İlk olarak 400 kuruş maaşla Molovişte köyü Ulah Mektebi 2. muallimliğinde bulunmuştur. Daha sonra 23 Ekim 1910'da 600 kuruş maaşla Manastır Umur-1 Nafia Kondüktörlüğüne tayin edilmiştir. ${ }^{50}$

\section{Esteryo Efendi}

Comit Ağa'nın oğlu olan Esteryo Efendi 1871'de Karaferye'nin Sele köyünde doğmuştur. İlköğrenimini Karaferye Ulah İptidaî Mektebi'nde gördükten sonra Manastır Ulah İdadisinde okumuştur. Ardından Romanya'ya gitmiş ve burada Bükreş Darülfünununda bir yıl okuduktan sonra Turuk ve Ma'abir Mektebinde eğitim görmüştür. Türkçe, Ulahça, Fransızca, Almanca ve Rumca bilmektedir. 5 Ocak 1898 'de 28 yaşında 500 kuruş maaşla Manastır 3. sınıf kondüktörlüğ̈̈ne atanmıştır. 10 Ocak 1904 tarihinde ise görevinden istifa etmiştir. ${ }^{51}$

\footnotetext{
${ }^{47}$ Memurlar alfabetik sıraya göre verilmiş, aynı isimli kişilerde ise doğum tarihi dikkate alınmıştır..

${ }^{48}$ BOA, DH.SAID.d, Nr: 153/192.

${ }^{49}$ BOA, DH.SAID.d, Nr: $171 / 119$

${ }^{50}$ BOA, DH.SAID.d, Nr: 178/247.

${ }^{51}$ BOA, DH.SAID.d, Nr: 79/219.
} 


\section{Esteryo Efendi}

Tüccar Yani'nin oğlu olup 1881'de Yanya'da doğmuştur. Manastır Ulah İdadisindeki öğreniminden sonra Bükreş Tıp Fakültesine kabul edilmiştir. Burada iki yıl eğitim görmüştür. Osmanlı Darülfünunu tıp şubesinden 17 Mayıs 1911 tarihinde tabiplik diplomasını almıştır. Türkçe, Rumca, Ulahça, Fransızca bilmektedir. 23 Mayıs 1911'de 600 kuruş maaş ve 400 kuruş tahsisatla Maçova Belediye tabipliğine atanmıştır. ${ }^{52}$

\section{Tanaş Kazane Efendi}

Tüccar Yorgi Efendi'nin oğludur. 1872'de Yanya'nın Vose köyünde doğmuştur. Yanya Sıbyan ve Rüşdiye Mekteplerindeki öğreniminden sonra Manastır Ulah İdadisinden mezun olmuştur. Bir süre Hukuk Mektebine devam etmiştir. Türkçe, Fransızca, Rumca ve Ulahça bilmektedir. Almanca ve İtalyancaya da aşinadır. 22 Ekim 1896'da 25 yaşında Matbuat-1 Ecnebiye, 8 Ağustos 1898'de de Hariciye Nezaretinin Umûr-1 Şehbenderî kalemlerine stajyer olarak devam etmiştir. ${ }^{53}$

\section{Vatola Efendi}

Orman memurluğu yapmış olan Vasil Adam'ın oğludur. 1867'de Kesriye'de doğmuştur. Manastır Ulah Mektebinde öğrenim gördükten sonra Mekteb-i Hukuka kabul edilmiş ancak 3. sınıfa kadar okuduktan sonra okulu terk etmiştir. Türkçe, Fransızca, Ulahça ve Rumca bilmekte, Bulgarcayı ise sadece konuşabilmektedir. 14 Mayıs 1889-2 Ağustos 1893 tarihleri arasında 500 kuruş maaşla Alasonya'da pasaport memurluğu yapmıştır. Daha sonra görevinden istifa etmişse de 2 Haziran 1897'de Kesriye Kaymakam Muavinliğine atanmıştır. Ancak uygunsuz davranışlarından dolayı memuriyeti tehir edilen Vatola Efendi 22 Temmuz 1897 tarihinde azledilmiştir. ${ }^{54}$

\section{Yorgi Dosyos Paşa}

Tüccar Nikolaki Efendi'nin oğludur. 1828'de Manastır'da doğmuştur. Manastır ve Atina İptidâilerinde ilköğrenimini gördükten sonra Yanya Darülfünun-1 T1bbîsinde sekiz yı1 eğitim görerek diploma almıştır. Ulahça, Rumca, Fransızca, Latince, Nemçece, Almanca, İtalyanca bilmekte, Türkçeyi yalnızca konuşabilmektedir. 1849 yılında 1.734 kuruş maaşla Beylerbeyi Hastanesi Tabipliğine atanmıştır. Daha sonra 2.000 kuruş maaşla Askerî Hastane, 29 Nisan 1861 tarihinde aynı maaşla Maltepe Hastanesi ve 22 Ocak 1867 'de 1.500 kuruş maaşla Haydarpaşa Hastanesi tabipliklerinde bulunmuştur. 7 Ağustos 1870'de Kuleli Hastanesi tabipliğine tayin edilmiştir. 9 Aralık 1875'te ikinci kez Maltepe Hastanesi, 5 Ocak 1876 tarihinde Bab-1 Zabtiye Tabipliğine nakledilmiştir. 13 Eylül 1875 tarihinde ayrıca Mabeyn-i Hümayun Eczanesinde görevlendirilmiştir. Bu görevde iken ilaveten kendisine İtfaiye Birinci Alayı Tabipliği de verilmiştir. 13 Eylül 1880 'de 1.200 kuruş maaşla 6. Daire-i Belediye Nisa Hastanesi tabipliğine tayin edilmiştir. 14 Şubat 1881 'de 2.000 kuruş maaşla İtfaiye Alayı tabiplik görevinden Askerî Hastane tabipliğine nakledilmiştir. 12 Mayıs 1887'de Nisa Hastanesindeki görevinden ayrılarak Haziran 1890'da 1.734 kuruş maaşla ikinci kez Beylerbeyi Hastanesi tabipliğine atanmıştır. 1865-1887 tarihleri arasında Dördüncü Rütbeden Mecidî, Dördüncü Rütbeden Osmânî ve Üçüncü Rütbeden Mecidî nişanları ile taltif edilmiştir. Ayrıca 7 Mart 1883 'te Salis, 9 Aralık 1885 'te Saniye Sınıf-1 Sanisi rütbelerini almıştır. 3

\footnotetext{
${ }^{52}$ BOA, DH.SAID.d, Nr: 182/27.

${ }^{53}$ BOA, DH.SAIDD.d, Nr: 89/76.; Taceddin Kayaoğlu, Osmanlı Hâriciyesinde Gayr-i Müslimler (1852-1925), Türk Tarih Kurumu Yayınları, Ankara 2013, s. 347.

${ }^{54}$ BOA, DH.SAID.d, Nr: 112/24.
} 
Kasım 1892 'de terfi ederek Saniye Sınıf-1 Mütemayizi ve 2 Aralık 1895 'te Mir-i mirân rütbelerine nail olmuştur. ${ }^{55}$

\section{Sonuç}

Romanya hükümeti Sultan Abdülhamid döneminde Osmanlı Devleti ile kurduğu diplomatik ilişkilerde Ulahların haklarını savunur bir pozisyon alarak onların çeşitli görevlerde istihdam edilmeleri ve hak ve hukuklarının genişletilmesi yönünde girişimlerde bulunmuştur. $\mathrm{Bu}$ girişimlerin de etkisiyle Ulahlardan bazı kişiler tabip, muallim, eczacı, muhtar, meclis azas1, mühendis, memur gibi değişik meslek gruplarında istihdam edilmişlerdir. Bunlardan görevlerini layıkıyla yerine getirenler gerek Osmanlı yönetimi gerekse yabancı devletler tarafindan nişan, rütbe ve madalyalarla ödüllendirilmiş, görevinde ihmali görülenler ise azledilmiştir. Osmanlı bürokrasisi içinde kısmen yer alan Ulahlar, Romanya'nın da desteği ile diğer Osmanlı milletlerinin yararlandığı haklardan yararlanmışlardır. Ulahlar Sultan Abdülhamid dönemi sonrasında da devlet içinde kendilerine yer bulacaklardır. Öyle ki 17 Aralık 1908'de açılan Osmanlı Mebusan Meclisinde bir Ulah mebus bulunmaktayd1. ${ }^{56}$ Zikredilen kişi Manastır Görice Mebusu Filip Mişe'dir. ${ }^{57}$ Seçimlerde meclise temsilci gönderebilecek çoğunluğa sahip olmamalarına rağmen Filip Mişe Efendi, İttihat ve Terakki Cemiyeti tarafından desteklenerek seçilmesi sağlanmıştır. Ayan Meclisine II. Abdülhamid'in atadığ 39 kişiden biri de Ulah kökenli Batzaria (Besarya) Efendi'dir. Nafia Nazırlığı yapan ve önde gelen Rumen gazetelerinden birinin muhabiri olan Besarya Efendi, 1913 yılında Londra'da Osmanlı hükümetinin barış delegesidir. 1908-1913 yılları arasında Osmanlı Meclisinde bir mebus, bir ayan ve bir nazır olmak üzere üç Ulah temsilci yer almıştır. ${ }^{58}$

${ }^{55}$ BOA, DH.SAID.d, Nr: 76/236.

${ }^{56}$ Makedonya, s. 92.

${ }^{57}$ Salname-i Devlet-i Aliyye-i Osmaniye, 1326, Selanik Matbaası, 65. Defa, s. 94.

Meclisin 3 Şubat 1909 tarihli oturumumda Girit konusunda söz alan Filip Mişe, Türkçe bildiğini ve Osmanlı olduğunu belirttikten sonra Yunanistan'ın ve Rumların Ulahlara yaklaşımından bahsetmiştir. Yunanistan'ın amacının Ulahları Rumlaştırmak ve böylece Osmanlı Devleti'nden bir parça koparmak olduğunu ifade etmiştir. Mișe Efendi'ye göre ne zaman Osmanlı Devleti'nin harici bir meselesi olduysa Yunanistan halkı ve Osmanlı vatandaşı Rumlar başlarında Patrik ve Metropolitleri olduğu halde içerde bir ihtilal çıkarmaya, Osmanlı Devleti aleyhine büyük Yunanistan'ı meydana getirmeye çalışmışlardır. Ulah efkârında olan Ulahların Osmanlı Devleti ile yaşamak ve Osmanlı Devleti ile ölmek için hazır bulunduğunu, bunun için İstanbul'daki Rum patriğinin Ulahları aforoz ettiğini dile getiren Mişe Efendi Rum terbiyesi görmüş olan Ulahların ise Yunanistan'ın emelleri için çalıştıklarını ifade etmiştir. (Meclis-i Mebusan Zabıt Ceridesi, İ: 22, C: 2, 21 Kanunusâni 1324, s. 450).

${ }^{58}$ Birecikli, s. 951-952. 


\section{KAYNAKÇA}

\section{Başbakanlık Osmanlı Arşivi (BOA)}

Babıali Evrak Odası (BEO)

Dâhiliye Nezâreti Mektubî Kalemi (DH. MKT)

Dahiliye Nezareti Sicill-i Ahvâl Defterleri (DH.SAID.d)

Irâde Dâhiliye (I.DH.)

Irâde Hususî (I.HUS)

Meclis-i Vükelâ Mazbataları (MV)

Rumeli Müfettişliği Sadâret (TFR.I.A.)

Rumeli Müfettişliği Makamat (TFR. I.MKM)

Rumeli Müfettişliği Selanik Evrakı (TFR. I.SL)

Sadaret Mektubî Kalemi Umum Vilâyât (A.MKT.UM.)

Yıldız Perakende Elçilik, Şehbenderlik ve Ataşemiliterlik (Y.PRK. EŞA)

Yıldız Sadâret Hususî (Y.A.HUS.)

\section{Süreli Yayınlar}

Meclis-i Mebusan Zabut Ceridesi

Salname-i Devlet-i Aliyye-i Osmaniye, 1326, Selanik Matbaas1, 65. Defa.

\section{Tetkik Eserler-Makaleler}

Akbayar, Nuri, Osmanlı Yer Adları Sözlüğü, Tarih Vakfı Yurt Yayınları, 2. Baskı, İstanbul 2001.

Andonyan, Aram, Balkan Savaşı, Çeviren: Zaven Biberyan, Aras Yayıncılık, İstanbul 1999.

Birecikli, İhsan Burak, "Balkanlarda Unutulmuş Bir Halk: Ulahların Kısa Tarihi”, Türk Tarihinde Balkanlar, C. II, Sakarya Üniversitesi Balkan Araştırmaları Uygulama ve Araştırma Merkezi Yayınları, Sakarya 2013, ss. 937-972.

Dimçev, Dimo N., "Osmanlı Döneminde Türk-Ulah Münasebetleri”, XIII. Türk Tarih Kongresi 4-8 Ekim 1999, Cilt: 3, K1sım: I, Türk Tarih Kurumu, Ankara 2002, ss. 125-132.

Garnett, Lucy M.J., Türkiye'nin Kadınları ve Folklorik Özellikleri, Oğlak Bilimsel Kitaplar, İstanbul 2009.

Harp Akademileri Komutanlığı, Makedonya, Harp Akademileri Basımevi, İstanbul 1992.

İleri, Celal Nuri, "Bulgar ve Pomak", Ankara Üniversitesi Dil ve Tarih-Coğrafya Fakültesi Dergisi, 53, 2 (2013), ss. 421-431.

Kayaoğlu, Taceddin, Osmanlı Hâriciyesinde Gayr-i Müslimler (1852-1925), Türk Tarih Kurumu Yayınları, Ankara 2013.

Köseoğlu, Mehmet, Başbakanlık Osmanlı Arşiv Belgelerine Göre Ulahların Siyasi, Dini ve Eğitim Faaliyetleri (1876-1910), Yüksek Lisans Tezi, Batman 
Üniversitesi\&Fırat Üniversitesi (Ortak Program) Sosyal Bilimler Enstitüsü, Elazığ 2015 .

Kutlu, Sacit, Milliyetçilik ve Emperyalizm Yüzyılında Balkanlar ve Osmanlı Devleti, İstanbul Bilgi Üniversitesi Yayınları, İstanbul 2007.

Malcolm, Noel, Kosova Balkanları Anlamak İçin, Türkçesi: Özden Arıkan, Sabah Kitapları, İstanbul 1999.

Sarıyıldız, Gülden, "Sicill-i Ahvâl Defterleri”, Türkiye Diyanet Vakfi İslâm Ansiklopedisi, Cilt 37, Türkiye Diyanet Vakfi Yayınları, İstanbul 2009, ss. 134-136.

Sepetçioğlu, Tuncay Ercan, “Türkiye'de Ana Dili Türkçe Olmayan Göçmen Topluluklara Yaklaşımlara Dair Bir Örnek: Girit Göçmenleri”, ÇTTAD, IX/20-21 (2010 BaharGüz), ss. 77-108.

Uzer, Tahsin, Makedonya Eşklyalık Tarihi ve Son Osmanlı Yönetimi, Türk Tarih Kurumu Yayınları, Ankara 1999.

Ünlü, Mucize, "II. Abdülhamid Döneminde Ulahlar", Türk-İslâm Medeniyeti Akademik Araştırmalar Dergisi, Sayı 7/Kış, Konya 2009, ss. 145-160.

Wachtel, Andrew Baruch, Dünya Tarihinde Balkanlar, Çeviren: Ali Cevat Akkoyunlu, Doğan Kitap, İstanbul 2009.

Yerasimos, Stefanos, Milliyetler ve Sinırlar Balkanlar, Kafkasya ve Ortadoğu, İletişim Yayınlar1, İstanbul 1994.

\section{E-Kaynaklar}

http://ataturkkitapligi.ibb.gov.tr/yordambt/yordam.php?

https://turkalemiyiz.com/Home/Getbalkanlar?categoryid=5\&aid=2049 
EK I: Filip Mişe Efendi’nin Fotoğrafı

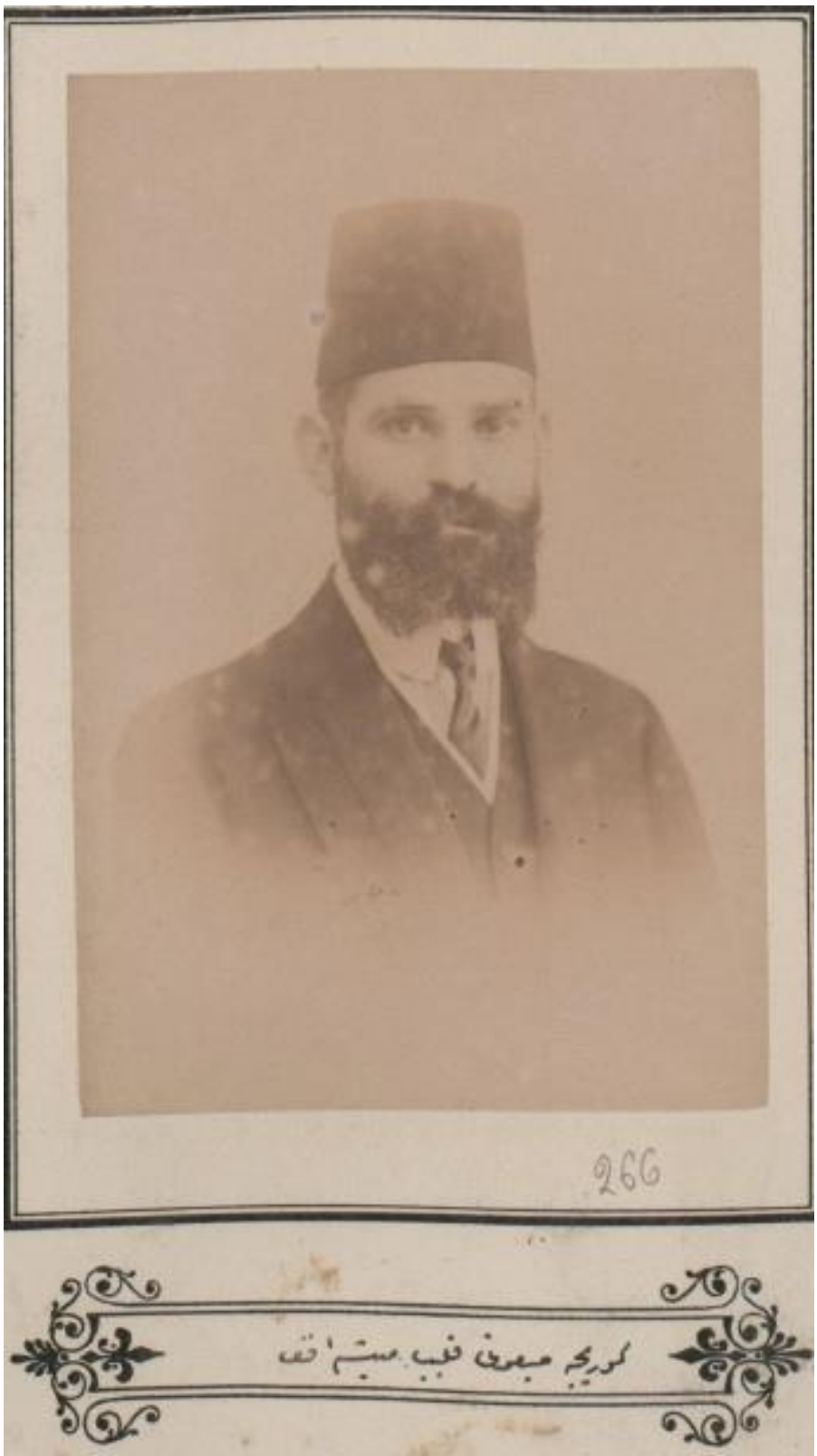

(Kaynak: http://ataturkkitapligi.ibb.gov.tr/yordambt/yordam.php? İstanbul Büyük Şehir Belediyesi Atatürk Kitaplığı Sayısal Arşiv ve e-Kaynaklar, Erişim Tarihi: 12.12.2018) 


\section{EK II: Sultan II. Abdülhamid'e Yazılan Ulahça Şiir}

SULTAN II. ABDÜLHAMID MARŞI

Sen, ulu ve haşmetli

Muzaffer Sultansin

Huzurunda, neşeli

Şarkımızı duyansın!

Sendedir hürriyet

Ulahlara, millete,

Azametle gayret

Hediyedir devlete!

Ey tanrım, kudretinle

Koru Şahımızı

Sonsuz merhametinle

Osmanlı tahtımızı

Bin borazanla gürler

Ulahın ülküsü

Padişaha ömürler

Diler Ulah türküsü!

Bin yıl yaşa Sultanım

Sanlı, ünlü ilhan

Sultanlar Sultan1,

Abdülhamid Han!

(Kaynak: https://turkalemiyiz.com/Home/Getbalkanlar?categoryid=5\&aid=2049, Erişim Tarihi: 12.12.2018) 